\title{
Heavy Metals Contamination and Physicochemical Properties of Nono Sold in Wushishi Local Government Area of Niger State, Nigeria
}

\author{
Kabiru, Adamu Y. ${ }^{1}$, Gwarjiko, Idris U. ${ }^{2 *}$ \\ ${ }^{I}$ Federal University of Technology, Minna, Nigeria \\ ${ }^{2}$ Assi College of Health Sciences and Technology, Madalla, Nigeria
}

\begin{abstract}
Dairy products such as Nono can be contaminated by heavy metals through exposure of lactating cows to pollution or consumption of feed and water with toxicants. Nono may also be exposed to toxicants during the processes of production and marketing. Nono samples were bought from hawkers around three locations, Zungeru, Wushishi and Gwarjiko, in Wushishi Local Government Area of Niger State, Nigeria. The Nono samples were wet digested and the concentrations of Lead (Pb), Magnesium (Mg), Manganese (Mn), Iron (Fe) and Zinc (Zn) were determined by the Flame Atomic Absorption Spectrophotometeric technique. Percentage lactic acid, $\mathrm{pH}$, total soluble sugar, \% moisture content and \% total solid were also determined using standard methods. The mean concentrations of $\mathrm{Pb}, \mathrm{Mg}, \mathrm{Mn}, \mathrm{Fe}$, and $\mathrm{Zn}$ were found to range from $0.756-0.769$ $\mathrm{mg} / \mathrm{L}, 0.379-0.390 \mathrm{mg} / \mathrm{L}, 0.351-0.354 \mathrm{mg} / \mathrm{L}, 1.075-1.080 \mathrm{mg} / \mathrm{L}$ and $0.234-0.389 \mathrm{mg} / \mathrm{L}$ respectively. The $\mathrm{pH}$, titratable acidity (expressed as \% lactic acid), total soluble sugar, \% moisture content and \% total solids were 3.85 - 4.06, 0.04 - 0.16\%, 5.67 $5.73,8.08-8.30 \%$ and $91.70-91.92 \%$ respectively. There was no statistical difference between the means when compared at $p \leq 0.05$, but the concentrations of lead, manganese and iron were found to be above the permissible levels while the $\mathrm{pH}$ was slightly lower than the acceptable limit. Continuous monitoring of cattle water and feed, and use of appropriate containers in transit of raw milk and (finished) Nono are necessary so as to safeguard milk products from pollution.
\end{abstract}

Keywords - Nono, Milk, Heavy metals, Physicochemical properties, Atomic Absorption Spectrophotometry

\section{INTRODUCTION}

$\mathrm{H}$ eavy metals are major environmental pollutants and continue to pose serious environmental and health hazards. They are released into the environment from natural as well as man-made activities. Some heavy metals are essential to maintain proper metabolic activity in living organisms $[1,2]$.

Zinc $(\mathrm{Zn})$ is useful in cell replication and gene expression, in nucleic acid and amino acid metabolism, vitamins $\mathrm{A}$ and $\mathrm{E}$ metabolism and bioavailability and normal testicular development among others [3, 4]. Manganese (Mn) serves as a cofactor of and activates many important enzymes including hydrolase, decarboxylase and transferases [5, 6] while Sodium $(\mathrm{Na})$ regulates plasma volume and acid-base balance, is involved in the maintenance of osmotic pressure of the body fluids, preserves normal irritability of muscles and cell permeability, activates nerve and muscle function and is involved in $\mathrm{Na}+\mathrm{K}+$-ATPase, maintenance of membrane potentials, transmission of nerve impulses and the absorptive processes of monosaccharides, amino acids, pyrimidines, and bile salts [7, 5]. However, at high concentrations, even this group of metals can become toxic to living organisms [8]. For example, high dietary sodium $(\mathrm{Na})$ is implicated in cardiovascular and renal disorders [9].

There are however many others that are non-essential [1, 2] and have devastating effects on the biological system even in small doses. Lead $(\mathrm{Pb})$, for example is reported to cause spontaneous abortion, kidney and brain damage and damage to nervous system $[10,11]$ while Cadmium $(\mathrm{Cd})$ is associated with renal problems, anemia, reproductive failure and other complications [12].

According to [13], rapid industrialization, use of agricultural chemicals and automobile exhaust fumes have caused an increase in the toxic heavy metals in the environment thereby affecting all; the global air, water and food, and the human population is directly affected through the food chain [13].

In recent times, the amount of metals in cow milk and its products have been widely studied, particularly in industrialized and polluted areas of the developed and the developing countries of the world like Nigeria since animals grazed freely on open fields are considered as bio-indicators of environmental pollution [14, 2, 15]. Metal level in uncontaminated milk is generally low, but by inhalation of polluted air, intake of contaminated feeds and absorption through the skin, many dangerous elements or compound such as metals and metalloid, accumulate along the food chain [16]. The toxicity of metals depends on a number of factors such as the particular metal in question, dose absorbed and the age of the individual concerned [17].

Toxicants, including heavy metals are continuously taken in by plants and subsequently, animals into their systems. Consequently, they find their way into the food chain which causes further distribution of these toxicants to the environment [18, 19]. This is the case in Nono that is consumed by humans. Heavy metals can contaminate milk 
and its products (Nono inclusive) through exposure of lactating cow to pollution or consumption of feeding stuffs and water with toxicants [20,21]. Moreover, contamination can also be attributed to the process of manufacturing dairy products where toxicants have the possibility to be included during the production process $[22,21]$ and likewise during marketing [23].

Milk is an opaque liquid produced by the mammary glands of female animals including man which provides the primary source of nutrition for newborn mammals before they are able to digest other types of food [24]. It enhances the postnatal adaptation of newborn by improving the digestive maturity, development of gut-associated lymphoid tissues and symbiotic microflora [25]. Nono is the Hausa name for locally defatted (skimmed) and fermented milk. It is one of the popular foods consumed in the Northern part of Nigeria; it is a product from raw milk obtained from cows, sheep or goats that is hardly pasteurized [26].

Nono is produced by locally defatting or skimming fresh milk for $30-45$ minutes and then left to ferment over night by a number of bacterial species from various sources that contaminate it. Also, some left over Nono (back slopping) from previous sale is added to aid fermentation process [27].

Despite the indicated toxicity risk associated with elevated levels of heavy metals in food stuff like milk and its products $[13,28]$, the contamination of cow's milk and its products (like Nono) has not been seriously studied so far in Niger State and particularly Wushishi Local Government Area. And the study area is also one where large agricultural as well as quarrying activities take place [29] which may translate to more risk of heavy metal contamination of food substances from the area and the environment in general. The aim of this study therefore was to evaluate heavy metals contamination and physicochemical properties of Nono sold in Wushishi Local Government Area of Niger State, Nigeria.

\section{MATERIALS AND METHODS}

\section{A. Sample Collection}

The samples were collected in plastic bottles $(500 \mathrm{ml}$ capacity) which had been thoroughly prewashed and sterilized, and then taken to the sampling site. Nono samples were bought in triplicates from hawkers and then homogenised. This made up a total of nine (9) Nono samples. An in-situ measurement of $\mathrm{pH}$ was done using a field $\mathrm{pH}$ meter and the sample bottles were tightly covered immediately after collection. The samples were then transported to the Central Services Laboratory, National Cereal Research Institute (NCRI), Baddegi, Niger State for physicochemical and spectrophotometric analyses. The samples were stored in a refrigerator at $4^{0} \mathrm{C}$ to slow down the rates of chemical reactions resulting from bacterial activity.

\section{B. Physicochemical Analysis}

1) Titratable Acidity (TTA): Ten milliliters (10ml) of Nono sample was measured into each of three $250 \mathrm{ml}$ conical flasks and then titrated with standardized $0.1 \mathrm{~N} \mathrm{NaOH}$ using phenolphthalein indicator, until a pink end point colour was observed. The titratable acidity was finally calculated using the acid factor of lactic acid $(0.009 \mathrm{~g})$ in the equation below [30].

$$
\begin{aligned}
& \text { Titratable Acidity (expressed as \% lactic acid) } \\
& =\frac{\text { Titre Value X Conc. of NaOH Xx }}{V}
\end{aligned}
$$

Where; Conc. of $\mathrm{NaOH}=0.1 \mathrm{M}$

$$
\begin{aligned}
& x=\text { Lactic Acid Factor }=0.009 \mathrm{~g} \\
& \mathrm{~V}=\text { Volume of Sample used }=10 \mathrm{~mL}
\end{aligned}
$$

2) Percentage Moisture Content and Percentage Total Solid: The percentage moisture content and percentage total solid were determined using the gravimetric method described by AOAC (2005). Two grams (2g) of Nono sample was weighed into previously washed, dried and weighed glass crucibles. The crucibles with the samples were then placed in a thermostatically controlled oven at $105^{\circ} \mathrm{C}$ for 5 hours till a constant weight of solid material was obtained. The crucibles were then removed and cooled in a dessicator and then weighed. The moisture content of the samples was calculated and expressed as a percentage using the following equation [30]:

Moisture Content (\%) $=\frac{W_{2}-W_{3}}{W_{2}-W_{1}} \times 100$

Where; $W_{l}=$ Weight of empty crucible

$W_{2}=$ Weight of empty crucible + wet sample

$W_{3}=$ Weight of empty crucible + dry sample

While the total solid was calculated and expressed as a percentage using the relation below:

Total Solids (\%) = $100-$ Moisture Content (\%)

3) Total Soluble Sugar (TSS): The total soluble sugar content was determined by placing a few drops of Nono sample on the prism surface of a hand-held Brix refractometer (ATAGO Manual Refractometer) and reading the results on a total percentage scale. The results were adjusted based on tabulated values for the temperature correction from the temperature of the sample $\left(25^{\circ} \mathrm{C}\right)$ to the reference temperature $\left(20^{\circ} \mathrm{C}\right)$ of the refractometer [30].

\section{Sample Digestion and Spectrophotometry}

The Nono samples were first digested using the modified method described by [31]. $10 \mathrm{~mL}$ each of the Nono samples was measured into a $100 \mathrm{~mL}$ digestion tube. Each of the tubes was labeled to avoid mix-up. Nitric acid $\left(\mathrm{HNO}_{3}\right)$, perchloric acid $\left(\mathrm{HClO}_{4}\right)$ and sulphoric acid $\left(\mathrm{H}_{2} \mathrm{SO}_{4}\right)$ were added in the ratio of $3: 2: 1$ and the mixture was thoroughly stirred until 
white fumes evolved. It was then digested at $210^{\circ} \mathrm{C}$ for $2 \mathrm{~h}$ and 30 minutes in an aluminum heating block. The digested sample was allowed to cool at room temperature. The clear solution obtained was decanted and diluted with distilled water before being filtered through Whatman Filter Paper No. 45. The volume of the filtrate was made up to $100 \mathrm{~mL}$ using distilled water. The procedure was repeated for all the remaining samples. Standard solutions were prepared in each case, before metal concentrations were determined and were used to eliminate sample standard matrix indifferences. The concentrations of Lead $(\mathrm{Pb})$, Magnesium $(\mathrm{Mg})$, Manganese $(\mathrm{Mn})$, Iron $(\mathrm{Fe})$ and Zinc $(\mathrm{Zn})$ in the digested Nono samples were determined using Flame Atomic Absorption Spectrophotometer (FAAS).

\section{Statistical Analysis}

The results were analysed using one-way analysis of variance (ANOVA) to determine statistical significance of differences in the mean concentrations of Iron (Fe), Manganese (Mn), Zinc ( $\mathrm{Zn})$, Lead ( $\mathrm{Pb})$, \&Magnesium (Mg), and the physicochemical properties of Nono samples from different districts, assuming that there were significant differences between mean values when compared at $\mathrm{p} \leq 0.05$. Statistics were calculated with the Statistical Package for Social Sciences version 20 (SPSS 20).

\section{RESULTS}

The physicochemical properties of Nono samples from the three representative locations in Wushishi Local Government Area of Niger State are presented in Table 1 below. The results reveal that ranges of $\mathrm{pH}$, titratable acidity (expressed as \% lactic acid), total soluble sugar, moisture content, and total solid were $3.85-4.06,0.04-0.16 \%, 5.67-$ $5.73,8.08-8.30 \%$ and $91.70-91.92 \%$ respectively across the three locations. The results were not statistically significant when the means were compared at $\mathrm{p} \leq 0.05$.

Table 2 below shows the means of the concentration of lead $(\mathrm{Pb})$, magnesium $(\mathrm{Mg})$, manganese $(\mathrm{Mn})$, iron $(\mathrm{Fe})$ and zinc ( $\mathrm{Zn}$ ) found in Nono samples from the three locations in Wushishi Local Government Area of Niger State. The results indicate that the levels of $\mathrm{Pb}, \mathrm{Mg}, \mathrm{Mn}, \mathrm{Fe}$ and $\mathrm{Zn}$ ranged from $0.756-0.769 \mathrm{mg} / \mathrm{L}, 0.379-0.390 \mathrm{mg} / \mathrm{L}, 0.351-0.354 \mathrm{mg} / \mathrm{L}$, $1.075-1.080 \mathrm{mg} / \mathrm{L}$ and $0.234-0.389 \mathrm{mg} / \mathrm{L}$ respectively.

The Nono samples from Zungeru contained the highest level of $\mathrm{Mn}(0.354 \pm 0.003)$ whereas $\mathrm{Mg}$ level was highest in samples from Wushishi $(0.390 \pm 0.003)$. However, Nono samples from Gwarjiko were found to contain the highest levels of $\mathrm{Pb}(0.769 \pm 0.005), \mathrm{Fe}(1.080 \pm 0.001)$ and $\mathrm{Zn}$ $(0.389 \pm 0.143)$.

In addition, Fe was the most abundant metal in the Nono samples from all the three locations of Zungeru, Wushishi and Gwarjiko (1.075 $\pm 0.005, \quad 1.079 \pm 0.002$ and $1.080 \pm 0.001$ respectively). However, the mean concentrations of each metal in Nono from the three locations, when compared at $\mathrm{p} \leq 0.05$ showed no statistical significance.
Table I: Physicochemical Properties of Nono Samples sold in Wushishi LGA of Niger State, Nigeria

\begin{tabular}{|c|c|c|c|}
\hline Parameter & Zungeru & Wushishi & Gwarjiko \\
\hline $\mathrm{pH}$ & $4.1 \pm 0.12$ & $4.0 \pm 0.24$ & $3.9 \pm 0.14$ \\
\hline Titratable Acidity (\%) & $0.12 \pm 0.01$ & $0.16 \pm 0.06$ & $0.04 \pm 0.02$ \\
\hline Total Soluble Sugar & $5.67 \pm 0.76$ & $5.73 \pm 1.14$ & $5.67 \pm 0.99$ \\
\hline Moisture Content (\%) & $8.30 \pm 0.61$ & $8.08 \pm 1.40$ & $8.18 \pm 1.14$ \\
\hline Total Solid $(\%)$ & $91.70 \pm 0.61$ & $91.92 \pm 1.40$ & $91.82 \pm 1.14$ \\
\hline
\end{tabular}

Values are means \pm SD of triplicate analyses

Table II: Concentrations of Heavy Metals in Nono Samples sold in Wushishi LGA of Niger State, Nigeria

\begin{tabular}{|c|c|c|c|}
\hline Heavy Metal $(\mathrm{mg} / \mathrm{L})$ & Zungeru & Wushishi & Gwarjiko \\
\hline Lead $(\mathrm{Pb})$ & $0.759 \pm 0.013$ & $0.756 \pm 0.006$ & $0.769 \pm 0.005$ \\
\hline Magnesium $(\mathrm{Mg})$ & $0.379 \pm 0.014$ & $0.390 \pm 0.003$ & $0.387 \pm 0.005$ \\
\hline Manganese $(\mathrm{Mn})$ & $0.354 \pm 0.003$ & $0.352 \pm 0.002$ & $0.351 \pm 0.001$ \\
\hline Iron $(\mathrm{Fe})$ & $1.075 \pm 0.005$ & $1.079 \pm 0.002$ & $1.080 \pm 0.001$ \\
\hline Zinc $(\mathrm{Zn})$ & $0.266 \pm 0.080$ & $0.234 \pm 0.072$ & $0.389 \pm 0.143$ \\
\hline
\end{tabular}

$\mathrm{NB}$ : Values are means $\pm \mathrm{SD}$ of triplicate analyses

\section{DISCUSSION}

This study revealed that Nono sold in Wushishi Local Government Area of Niger State are highly acidic since they have $\mathrm{pH}(3.85,4.04$ and 4.06$)$ lower than the acceptable range of $6.5-6.7$ for raw and fermented milk [32]. This could be attributable to the process of production which includes the common practice of back slopping with Nono from previous sales [27] thus increasing rate of fermentation and causing a drop in $\mathrm{pH}$. This constitutes concern for the consumers because of the health implications of increased risk of lactic acidosis. This finding is in consonance with those of [27, 33, 34].

The study also revealed that Nono sold in the local government have very appreciable levels of titratable acidity, total soluble sugar and total solids since the values are all within acceptable limits [32]. This is contrary to the report of [34].

The findings of this study further showed that Nono sold in Wushishi Local Government Area of Niger State, Nigeria contain significantly high concentrations of lead $(\mathrm{Pb}=0.756-$ $0.769 \mathrm{mg} / \mathrm{L})$, manganese $(\mathrm{Mn}=0.379-0.390 \mathrm{mg} / \mathrm{L})$ and iron $(\mathrm{Fe}=1.075-1.080 \mathrm{mg} / \mathrm{L})$ exceeding the permissible limits of $0.017-0.030 \mathrm{mg} / \mathrm{L}, 0.026-0.060 \mathrm{mg} / \mathrm{L}$, and $0.21-0.70$ $\mathrm{mg} / \mathrm{L}$ respectively for the metals $[35,36,37,38]$. These elevated levels of heavy metals consumed are a matter of public health concern for the consumers and even the animals from which the milk for the Nono is obtained since studies have shown they can cause an array of disease conditions and disorders in their systems [13, 28]; sometimes by even interacting with other metals and biomolecules. For instance, high concentration of lead inhibits ferrochelatase, the enzyme 
responsible for the incorporation of iron in the porphyrin ring resulting in an accumulation of protoporphrin IX in the erythrocyte. The inhibition of $\alpha$-amino levulinic acid dehydratase activity, decrease in red cell survival, decrease in the rate of globin synthesis and an inhibition of the haeme synthesis are also attributable to lead [39].

The high levels of lead, manganese and iron could be due to climatic factors such as wind, use of agro-chemicals by farmers and very importantly, fodder and drinking water contamination. Furthermore, some of these cows graze around sites where quarrying activities take place and along roadsides where lead $(\mathrm{Pb})$ which is a fuel additive could be emitted from car exhausts to contaminate the environment.

These findings are similar to previous studies of [40, 41, $42,43,34]$ who also reported mean concentrations of metals in cow milk higher than the acceptable ranges. However, [44, $45,46,47]$ reported values not exceeding the permissible levels in their studies.

It has also been demonstrated by the findings of this study that the range of concentrations of magnesium $(0.379-0.390$ $\mathrm{mg} / \mathrm{L})$ and zinc $(0.234-0.389 \mathrm{mg} / \mathrm{L})$ are below the set acceptable limits of $97-146 \mathrm{mg} / \mathrm{L}$ and $3.5-4.2 \mathrm{mg} / \mathrm{L}$ respectively [36, 37, 48]. Although their concentrations did not exceed the maximum levels, they were also far below the minimum levels. This could also pose a health issue for the consumers since they may not be getting the recommended daily dose of the metals from consuming the Nono thus making them susceptible to hypomagnesemia and zinc deficiency. Acute hypomagnesemia results in vasodilation, with erythemia and hyperaemia appearing a few days on the deficient diet. Neuromuscular hyperirritability increases with the continuation of the deficiency, and may be followed eventually by cardiacarrhythmia and generalized tremours [7]. The animals could also be suffering from the same conditions. This finding agrees with those of $[16,42,49]$.

\section{CONCLUSION}

This study evaluated some heavy metals and physicochemical properties of Nono sold in Wushishi Local Government Area of Niger State, Nigeria. The acidic profile, elevated concentrations of lead, manganese and iron far exceeding the permissible limits, and very low levels of magnesium and zinc in the Nono samples is a cause for public health concern for consumers. Hence, continuous control and monitoring of water and feed for cattle and use of appropriate containers (like clean plastic or stainless steel containers instead of iron-made containers) in transit of raw milk and (finished) Nono is suggested so as to ensure the production of healthier Nono. Magnesium and zinc supplementation in the feed of the animals is important so as to improve their content in the dairy products hence increasing the chance of getting the minimum daily allowance for both minerals. Public enlightenment and health promotion is also very essential among the population.

\section{REFERENCES}

[1] Ayar, A., Sert, D., \& Akin, N. (2009) The trace metal levels in milk and dairy products consumed in middle Anatolia-Turkey. Environmental Monitoring Assessment, 152: 1-12.

[2] Qin, L., Wang, X. P., Li, W., Tong, X., \& Tong, W. J. (2009) The Minerals and Heavy Metals in Cow's Milk from China and Japan. Journal of Health Science, 55(2): 300-305.

[3] Szabo, G., Chavan, S., Mandrekar, P., \& Catalano, D. (1999) Acute Alcoholic Consumption Attenuates IL-8 and MCP-1 Induction in Response to Ex-vivo Stimulation. J. Clin. Immunol., 19: $67-76$.

[4] Merck, V. M. (1986) The Merck Veterinary Manual: A Handbook of Diagnosis, Therapy and Disease Prevention and Control for the Veterinarian. (6th ed.). Rahway, New Jersey, USA: Merck and Co. Inc.

[5] Murray, R. K., Granner, D. K., Mayes, P. A. \& Rodwell, V. W. (2000) Harper's Biochemistry (25th ed.). New York: McGrawHill.

[6] Chandra, R. K. (1990) Micro-nutrients and Immune Functions: An Overview. Annual New York Acad. Sci., 587: 9-16.

[7] Hays, V. W. \& Swenson, M. (1985) Minerals and Bones. In: Dukes, H. H. \& Melvin, J.S., Dukes' Physiology of Domestic Animals (10th ed.). London, UK: Cornell University Press. pp. 449-466

[8] Li, Y., McCrory, D., Powel, J., Saam, H., \& Jackson-Smith, D. (2005) A Survey of Selected Heavy Metal Concentrations in Wisconsin Dairy Feeds. Journal of Dairy Science, 88: 2911-2922.

[9] Soetan, K., Olaiya, C., \& Oyewole, O. (2010) The Importance of Mineral Elements for Humans, Domestic Animals and Plants: A Review. African Journal of Food Science, 4(5): 200-222.

[10] Bryee-Smith, O. \& Stephenes, R. (1982) Lead and Brian Function. Dev. Med. Child Neutral, 24: 90-91.

[11] Tunali, S., Cabuk, A., \& Akar, A. (2006) Removal of Lead and Copper Ions from Aqueous Solutions by Bacterial Strain Isolated from Soil. Chemical Engineering Journal, 115: 203-211.

[12] Murthy, G., \& Reha, U. (1971). Cadmium, Copper, Iron, Lead, Manganese and Zinc in Evaporated Milk Infant Products. Journal of Dairy Science, 54: 1001-1005.

[13] Abera, M. (2014) "Determination of Levels of Some Heavy Metals ( $\mathrm{Pb}, \mathrm{Cr}$ AND Cd) in Three Commercially Available Brands of Milk Powder Found in Harar Town, Eastern Hararge, Ethiopia." Unpublished M.Sc. Thesis, Haramaya University, Ethiopia.

[14] Korenekovg, B., Skalicka, M., \& Nai, P. (2002) Concentration of Some Heavy Metals in Cattle Reared in the Vicinity of Metallurgic Industry. Vetinery Archive, 72: 254-267.

[15] Sarsembayeva, N. B., Abdigaliyeva, T. B., Utepova, Z. A., Biltebay, A. N. \& Zhumagulova, S.Zh. (2020) Heavy metal levels in milk and fermented milk products produced in the Almaty Region, Kazakhstan. Veterinary World, 13(4): 609-613.

[16] Semaghuil, B., Simona, D., Stanciu, G., \& Soceanu, A. (2008) Determination of Major and Minor Elements in Milk through ICPAES. Environmental Engineering and Management Journal, 6: 805-808.

[17] Samara, S., \& Richard, H. (2009) Heavy Metal Toxicity, Medicine Specialist, Emergency Medicine Toxicology. New York.

[18] Ahmad, W. M. (2003) "Studies on Heavy Metal Pollution in Poultry Farms in Relation to Production Performance." Unpublished PhD Thesis, Zagazig University, Egypt.

[19] Ogabiela, E. E., Oklo, A. D., Yebpella, G. G., Ade-Ajayi, A. F., Mmereola, U. J., Ezeayanaso, C. S., Okonko, E. M., Udiba, U. U., Mahmood A. \& Gandu, I. (2010) Determination of Level of Some Elements in Edible Oils Sold in Zaria, Northern Nigeria. Global Journal of Pure and Applied Sciences, 16(3): 325-331.

[20] Carl, M. (1991) Heavy Metals and Other Trace Elements. Monograph on Residues and Contaminants in Milk and Milk Products. International Dairy Federation “IDF”, 9101(Belgium Special Issue): 112-119.

[21] Okada, I., Sakuma, A., Maio, F., Dovidauskas, S., \& Zenebon, O. (1997) Evaluation of Lead and Cadmium Levels in Milk Due to 
Environmental Contamination in Parabia Valley Region of SouthEastern Brazil. Revista-de-Saude-Publica, 31(2): 140-143.

[22] El-Batanouni, M. M., \& Abo-El-Ata, G. (1996) "Metals in Food." Conference on Food-Borne Contamination and Egyptian's Health, (pp. 11-27). Mansoura.

[23] Ijah, J., Odagboyi, G., \& Uwabujo, A. (2002) Microbiological Screening of Fura da Nono. Nigerian Journal of Science \& Technology and Mathematics Education, 5(1): 9-16.

[24] Barnabas, B. B., Ayodele, O. P., Gana, J., Jiya, A. \& Igheghe, F. (2014) Microbiological Assessments of Raw Cow Milk, Nono and Locally Fermented Cheese sold at Different Markets in Bida, Bida LGA, Niger State, Nigeria. IOSR Journal of Pharmacy and Biological Sciences, 9(5V): 19-22.

[25] Ebringer, L., Ferencik, M., \& Krajcovica, J. (2008) Beneficial Health Effects of Milk and Fermented Dairy Products. Folia Microbiology, 53: 378-394.

[26] Chukwuma, M. (2009) Furors Over Animal Milk Products Rage. World Journal of Microbiology and Biotechnology, 5(6): 23-30.

[27] Okeke, K., Abdullahi, I. O., \& Makun, H. (2014) Microbiological Quality of Dairy Cattle Products. British Microbiology Research Journal, 4(12): 1409-1417.

[28] Simsek, O., Gultekin, R., Oksuz, O., \& Kurultay, S. (2002) The Effect of Environmental Pollution on the Heavy Metal Contents of Raw Milk. Nahrung, 44: 360 .

[29] Murtala, B. M. (2005) "Local Government as a Vehicle for Rural Development: A Case Study of Wushishi Local Government Area of Niger State." MPA Thesis, Ahmadu Bello University, Zaria, Nigeria.

[30] AOAC. (2005) Official Methods of Analysis, Association of Official Analytical Chemists (15 ed.). (H. W., \& L. G.W., Eds.) Mariland, USA: AOAC International.

[31] Kolapo, A. A. (2014) Assessments of Natural Radioactivity and Heavy Metals in Commonly Consumed Milk in Oke-Ogun Area, Nigeria and Estimation of Health Risk Hazard to the Population. Journal of Environmental and Analytical Toxicology, 5(2): 1-5.

[32] McCarthy, O. J. \& Singh, H. (2009) "Physicochemical Properties of Milk." In: McSweeney, P. L. \& Fox, P. F. (Eds.), Advanced Dairy Chemistry, Vol. 3: Lactose, Water, Salts and Minor Constituents (Vol. 3, pp. 691-758). Springer Science + Business Media.

[33] Egwaikhide, P. A., Malu, P. S., Lawal, U., Adelagun, R. O. \& Andrew, C. (2014) Physicochemical and Microbiological Analysis of Fermented Cow Milk (Nono) Consumed Within Kaduna Town, North-Western Nigeria. Food Science and Quality Management, 29: 44-49.

[34] Damtew, E.T. \& Gebre, A.B. (2020) Chemical Composition and Heavy Metals Analysis of Raw Cow's Milk. Journal of Environmental \& Analytical Toxicology, 10(3): 1-5.

[35] Iyenga, G. V. (1982) Elemental Composition of Human and Animal Milk: A Review. Joint IAEA/WHO. Vienna: International Atomic Energy Agency. pp. 19-145.

[36] Renne, E., Schaafsma, G., \& Scottk, J. (1989) "Micronutrients in Milk." In: Renner, E. (ed.), Micronutrients in Milk and Milk-based Food Products (Vol. 1, pp. 1-70). England: Elsevier Science Publishers Ltd.
[37] Hunt, C. D. \& Nielson, F. H. (2009) Nutritional Aspects of Minerals in Bovine and Human Milks. In: McSweeney, P. L., \& Fox, P. F. (Eds.), Advanced Dairy Chemistry Vol. 3: Lactose, Water, Salts and Minor Constituents (Third ed., pp. 391 - 456). New York, USA: Springer Science + Business Media, LLC.

[38] Codex Alimentarius Commission. (2015) Joint FAO/WHO General Standard for Contaminants and Toxins in Food and Feed (CODEX STAN 193-1995). International Food Standards, (pp. 42-46).

[39] Elatrash, S. \& Atoweir, N. (2014) Determination of Lead and Cadmium in Raw Cow's Milk by Graphite Furnace Atomic Absorption Spectroscopy. Int. J. Chem. Sci., 12 (1): 92-100.

[40] Ogabiela, E. E., Udiba, U. U., Adesina, O. B., Hammuel, C., AdeAjayi, F. A., Yebpella, G. G., Mmereole, U. J. \& Abdullahi, M. (2011) Assessment of Metal Levels in Fresh Milk from Cows Grazed Around Challawa Industrial Estate of Kano, Nigeria. Journal of Basic and Applied Scientific Research, 1(7): 533 - 538.

[41] Jigam, A. A., Dauda, B. E., Jimoh, T., Yusuf, H. N., \& Umar, Z. T. (2011) Determination of Copper, Zinc, Lead and some Biochemical Parameters in Fresh Cow Milk from Different Locations in Niger State, Nigeria. African Journal of Food Science, 5(3): 156-160.

[42] Zodape, G. V., Dhawan, V. L., \& Wagh, R. R. (2012) Determination of Metals in Cow Milk Collected from Mumbai City, India. ECO Revolution, 244(17): 270-274.

[43] Kazi, M. A. (2015) Mineral Analysis of Milk through Atomic Absorption Spectroscopy and their Biological Role in Human Life. Int'l Journal of Advances in Chemical Engg., \& Biological Sciences (IJACEBS), 2(2): 113-115.

[44] Shahriar, S. M., Akther, S., Akter, F., Morshed, S., Alam, M. K., Saha, I., Halim, M. A. \& Hassan, M. M. (2014) Concentration of Copper and Lead in Market Milk and Milk Products of Bangladesh. International Letters of Chemistry, Physics and Astronomy, 27: 56-63.

[45] Aniello, A., Rosa, C., Maria, M., Catellani, P., Maria, R., Salvatore, P. \& Cortesi, M. L. (2006) Heavy Metal Concentrations in Dairy Products from Sheep Milk Collected in Two Regions of Southern Italy. Acta Vet. Scand., 47(1): 69-74.

[46] Batool, F., Iqbal, S., Tariq, M. I., Akbar, J., Noreen, S., Danish, M. \& Wei, K. C. (2016) Milk: Carrier of Heavy Metals from Crops through Ruminant Body to Human Beings. J. Chem. Soc. Pak., 38 (01): $39-42$.

[47] Sarsembayeva, N. B., Abdigaliyeva, T. B., Utepova, Z. A., Biltebay, A. N. \& Zhumagulova, S.Zh. (2020) Heavy metal levels in milk and fermented milk products produced in the Almaty Region, Kazakhstan. Veterinary World, 13(4): 609-613.

[48] Gaucheron, F. (2005) The minerals of milk. Reprod. Nutr. Dev., 45: $473-483$.

[49] Shahbazi, Y., Ahmadi, F. \& Fakhari, F. (2016) Voltammetric determination of $\mathrm{Pb}, \mathrm{Cd}, \mathrm{Zn}, \mathrm{Cu}$ and $\mathrm{Se}$ in milk and dairy products collected from Iran: An emphasis on permissible limits and risk assessment of exposure to heavy metals. Food Chemistry, 192: 1060-1067. 